With compliments of the Author 


\title{
A Novel and Efficient Route for the Synthesis of Hydroxylated 2,3-Diarylxanthones
}

\author{
Clementina M. M. Santos, ${ }^{\mathrm{a}, \mathrm{b}}$ Artur M. S. Silva, ${ }^{* b}$ José A. S. Cavaleiro ${ }^{\mathrm{b}}$ \\ a Department of Agro-Industries, Escola Superior Agrária de Bragança, Campus de Santa Apolónia, 5301855 Bragança, Portugal \\ b Department of Chemistry, University of Aveiro, Campus Universitário de Santiago, 3810193 Aveiro, Portugal \\ Fax +351(23)4370084; E-mail: artur.silva@ua.pt \\ Received 27 July 2007
}

\begin{abstract}
A novel, efficient and general route for the synthesis of hydroxylated 2,3-diarylxanthones is described. 3-Bromo-2-styrylchromone, the key intermediate of this synthesis, is obtained by a Baker-Venkataraman rearrangement of the appropriate 2 '-cinnamoyloxyacetophenone, followed by a one-pot reaction with phenyltrimethylammonium tribromide. The Heck reaction of these bromochromones with substituted styrenes gives methoxylated 2,3diarylxanthones. The cleavage of the methyl groups with $\mathrm{BBr}_{3}$ gives the desired hydroxylated 2,3-diarylxanthones.
\end{abstract}

Key words: hydroxylated diarylxanthones, 3-bromo-2-styrylchromones, phenyltrimethylammonium tribromide, Heck reaction, demethylation

Xanthones are a class of oxygenated heterocyclic compounds widely occurring as secondary metabolites in some higher plant families, fungi and lichens. ${ }^{1}$ These natural derivatives can exhibit numerous substitutions at different positions of their skeleton: methoxy, hydroxyl and glycosyl groups being the most frequently occurring ones. $^{2}$

The pharmacological properties of both natural and synthetic xanthone derivatives have been extensively reported in the literature ${ }^{3}$ they include antiallergic, ${ }^{4}$ antifungal, ${ }^{5}$ anti-inflammatory, ${ }^{6}$ antimalarial ${ }^{7}$ and antitumour activities ${ }^{8}$ and this reveals the growing interest in this type of compounds.

One of the most promising properties of xanthones is related to their application as antioxidant agents. ${ }^{9}$ The aromatic character and the presence of hydroxyl groups and/ or cathecol moieties at certain positions of the xanthone core are requirements for a strong antioxidant activity..$^{10} \mathrm{It}$ is worth mentioning that there are already two formulations in the market containing oxygenated and prenylated xanthones, as antioxidants. ${ }^{11}$

Taking into consideration the referred structural characteristics for a high antioxidant activity, we developed a novel route for the synthesis of hydroxylated 2,3-diarylxanthones. The classical methods widely described for the synthesis of xanthones (e.g. Friedel-Crafts acylation, Fries rearrangement or Ullmann condensation) $)^{12}$ do not allow the synthesis of our target compounds. Moreover,

SYNLETT 2007, No. 20, pp 3113-3116

Advanced online publication: 21.11.2007

DOI: 10.1055/s-2007-990900; Art ID: D23507ST

(c) Georg Thieme Verlag Stuttgart · New York our previous work on the synthesis of xanthones, using the 3-bromo-2-methylchromone ${ }^{13}$ as key intermediate was not effective in the synthesis of 2-aryl-3-(3,4-dihydroxyphenyl)xanthone derivatives, since the condensation of 3bromo-2-methylchromone with 3,4-dioxygenatedbenzaldehydes does not occur. To circumvent these difficulties we have developed a general method for the synthesis of hydroxylated 2,3-diarylxanthones, starting from 2'-hydroxyacetophenone (1) and cinnamic acid derivatives $\mathbf{2 a -}$ c (Schemes 1-3), for further evaluation of the antioxidant activity.

The first part of the new synthetic route considers the preparation of 3-bromo-2-styrylchromones 5a-c by a three-step sequence depicted in Scheme 1. It started by the cinnamoylation of $2^{\prime}$-hydroxyacetophenone (1) with commercially available cinnamoyl chloride (2a) or with the in situ prepared acid chlorides from cinnamic acids $\mathbf{2 b}, \mathbf{c}$ and phosphoryl chloride, affording the corresponding 2 '-cinnamoyloxyacetophenones $3 \mathbf{a}-\mathbf{c}$. The second step consisted of the cinnamoyl group transposition from the 2 'position to the 2-position of the acetophenone moiety, which is known as the Baker-Venkataraman rearrangement. ${ }^{14}$ It was performed by treatment of $\mathbf{3 a - c}$ with potassium hydroxide in DMSO to afford 5-aryl-3-hydroxy-1(2-hydroxyphenyl)-2,4-pentadiene-1-ones $\mathbf{4 a - c}$, in good yields (73-95\%). The last step consisted of a novel onepot synthesis, involving bromination and cyclization reactions, giving rise to the desired 3-bromo-2-styrylchromones 5a-c $(53-67 \%){ }^{15,16}$ The $\alpha$-ketone bromination was selectively carried out with phenyltrimethylammonium tribromide (PTT) ${ }^{17}$ while the cyclodehydration of the obtained brominated compounds occurred probably due the acidic conditions originating during the bromination reaction.

The Heck cross-coupling reaction is one of the most powerful and efficient methods for carbon-carbon bond formation and consists of a palladium-catalyzed reaction involving olefins and vinyl or aryl halides. ${ }^{18}$ In the present study, 3-bromo-2-styrylchromones 5a-c were used as vinyl halides and styrenes $\mathbf{6 a - c}$ as olefins (Scheme 2). ${ }^{19} \mathrm{Op}-$ timization studies were performed to determine the influence of bases, phosphines, palladium catalysts, temperature and reaction time on the coupling reaction. The best results were obtained with one equivalent of triethylamine as base, 0.1 equivalent of triphenylphosphine and $5 \mathrm{~mol} \%$ of tetrakis(triphenylphosphine)palladium $(0)$ as 


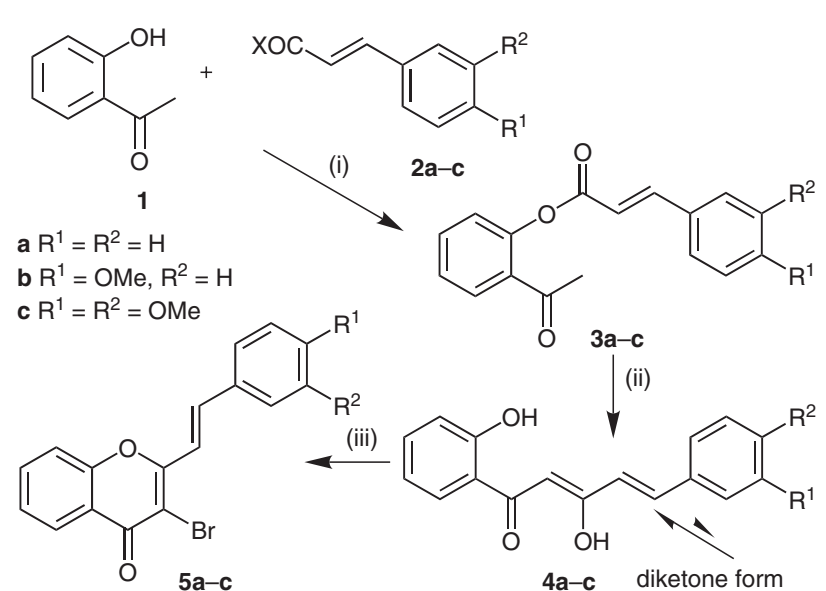

Scheme 1 Reagents and conditions: (i) (a) $\mathrm{X}=\mathrm{Cl}$, anhyd pyridine, r.t., $2 \mathrm{~h}$; (b) $\mathrm{X}=\mathrm{OH}, \mathrm{POCl}_{3}$, anhyd pyridine, $60^{\circ} \mathrm{C}, 2 \mathrm{~h}$; (ii) DMSO, $\mathrm{KOH}$, r.t., 2 h; (iii) PTT, THF, r.t., 12 h.

catalyst. Under these conditions the desired 2,3-diarylxanthones $7 \mathbf{a}-\mathbf{i}^{20}$ and the semioxidized intermediates 2,3diaryl-3,4-dihydroxanthones $\mathbf{8 a}-\mathbf{i}^{21}$ were obtained (Scheme 2, Table 1). The formation mechanism of xanthones $7 \mathbf{a}-\mathbf{i}$ and $\mathbf{8} \mathbf{a}-\mathbf{i}$ is similar to those presented in our previous work. ${ }^{13}$

Demethylation of 2,3-diarylxanthones $\mathbf{7 b}-\mathbf{i}$ was achieved by their treatment with boron tribromide ${ }^{22}$ in anhydrous dichloromethane (Scheme 3). ${ }^{23}$ The hydroxylated 2,3-diarylxanthones $\mathbf{9 b}-\mathbf{i}^{24}$ were obtained in good yields $(70$ 94\%).

All the synthesized compounds have been characterized by NMR, MS and elemental analysis. In the ${ }^{1} \mathrm{H}$ NMR spectra of 5-aryl-3-hydroxy-1-(2-hydroxyaryl)-2,4-pentadien-1-ones $\mathbf{4 a - c}$ it is possible to observe the presence of two singlets at $\delta=12.23-12.28 \mathrm{ppm}$ and $\delta=14.65-14.75$ $\mathrm{ppm}$, which are due to the resonances of protons involved in hydrogen bonds. One can conclude that the compounds 4a-c exist in enolic forms, as shown in Scheme 1, and the former signals correspond to the resonances of the phenolic protons whereas the latter ones are due to the $3-\mathrm{OH}$ protons.

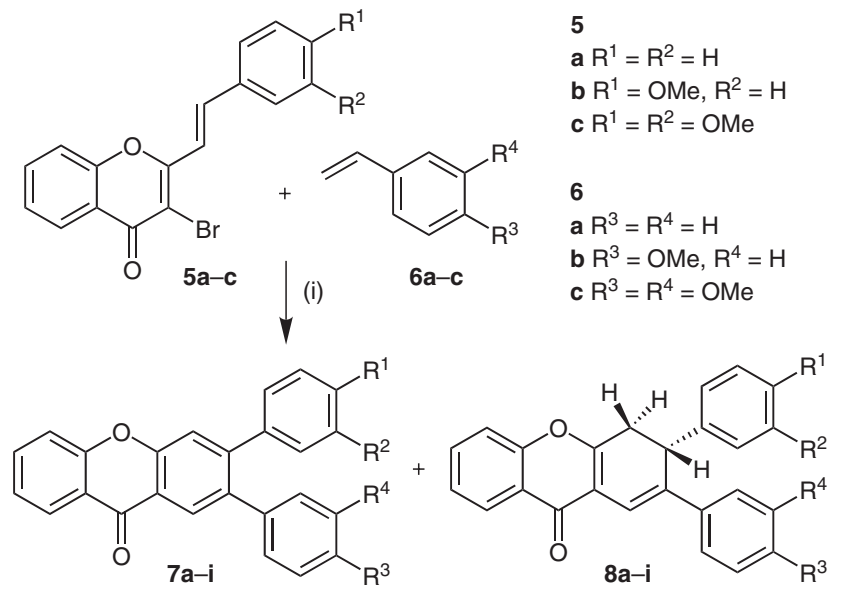

Scheme 2 Reagents and conditions: (i) NMP, $\mathrm{Et}_{3} \mathrm{~N}, \mathrm{PPh}_{3}$, $\mathrm{Pd}\left(\mathrm{PPh}_{3}\right)_{4}$.

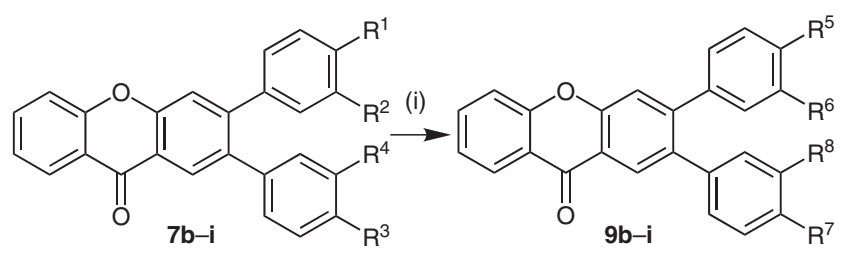

$R^{1}, R^{2}, R^{3}, R^{4}=H, O M e$ $R^{5}, R^{6}, R^{7}, R^{8}=H, O H$

Scheme 3 Reagents and conditions: (i) (a) anhyd $\mathrm{CH}_{2} \mathrm{Cl}_{2}, \mathrm{BBr}_{3}$, $-78^{\circ} \mathrm{C}$ to r.t.

The main features in the ${ }^{1} \mathrm{H}$ NMR spectra of 3-bromo-2styrylchromones $\mathbf{5 a}-\mathbf{c}$ are the doublets corresponding to the resonances of the two vinylic protons $\mathrm{H}-\alpha$ and $\mathrm{H}-\beta$ in the trans configuration $\left({ }^{3} J_{\mathrm{H} \alpha-\mathrm{H} \beta}=15.8-16.0 \mathrm{~Hz}\right)$. The resonances assigned to $\mathrm{H}-\beta(\delta=7.66-7.73 \mathrm{ppm})$ and $\mathrm{C}-\beta$ $(\delta=139.3-139.6 \mathrm{ppm})$ appears at higher frequency values than those of $\mathrm{H}-\alpha(\delta=7.33-7.51 \mathrm{ppm})$ and $\mathrm{C}-\alpha(\delta=$ 116.7-119.2 ppm), due to the mesomeric deshielding effect of the carbonyl group. An important characteristic of the ${ }^{1} \mathrm{H}$ NMR spectra of 2,3-diarylxanthones $7 \mathbf{a}-\mathbf{i}$ and $\mathbf{9 b}-$ $\mathbf{i}$ are the singlets corresponding to the resonances of $\mathrm{H}-1$ $(\delta=7.98-8.39 \mathrm{ppm})$ and $\mathrm{H}-4(\delta=7.50-7.65 \mathrm{ppm})$. H-1 appears at higher frequency values due to the anisotropic

Table 1 Heck Reaction of 3-Bromo-2-styrylchromones 5a-c with Styrenes 6a-c

\begin{tabular}{|c|c|c|c|c|c|c|c|c|}
\hline Compd 7/8 & $\mathrm{R}^{1}$ & $\mathrm{R}^{2}$ & $\mathrm{R}^{3}$ & $\mathrm{R}^{4}$ & Temp. & Time (h) & Yield of $7(\%)$ & Yield of $\mathbf{8}(\%)$ \\
\hline $\mathbf{a}$ & $\mathrm{H}$ & $\mathrm{H}$ & $\mathrm{H}$ & $\mathrm{H}$ & $160^{\circ} \mathrm{C}$ & 9 & 54 & 9 \\
\hline b & $\mathrm{H}$ & $\mathrm{H}$ & $\mathrm{OMe}$ & $\mathrm{H}$ & $160{ }^{\circ} \mathrm{C}$ & 3 & 66 & 14 \\
\hline c & $\mathrm{H}$ & $\mathrm{H}$ & $\mathrm{OMe}$ & $\mathrm{OMe}$ & $160^{\circ} \mathrm{C}$ & 12 & 44 & 6 \\
\hline d & $\mathrm{OMe}$ & $\mathrm{H}$ & $\mathrm{H}$ & $\mathrm{H}$ & reflux & 9 & 60 & 11 \\
\hline e & $\mathrm{OMe}$ & $\mathrm{H}$ & $\mathrm{OMe}$ & $\mathrm{H}$ & reflux & 3 & 46 & 11 \\
\hline $\mathbf{f}$ & $\mathrm{OMe}$ & $\mathrm{H}$ & $\mathrm{OMe}$ & $\mathrm{OMe}$ & reflux & 3 & 21 & 4 \\
\hline g & $\mathrm{OMe}$ & $\mathrm{OMe}$ & $\mathrm{H}$ & $\mathrm{H}$ & reflux & 9 & 62 & 3 \\
\hline h & $\mathrm{OMe}$ & $\mathrm{OMe}$ & $\mathrm{OMe}$ & $\mathrm{H}$ & reflux & 6 & 46 & 21 \\
\hline $\mathbf{i}$ & $\mathrm{OMe}$ & $\mathrm{OMe}$ & $\mathrm{OMe}$ & $\mathrm{OMe}$ & reflux & 9 & 55 & 6 \\
\hline
\end{tabular}


and mesomeric deshielding effect of the carbonyl group. The assignment of proton $\mathrm{H}-1$ was also confirmed by the connectivity found in the HMBC spectrum between the singlet at higher frequency value and the carbonyl carbon. In the ${ }^{1} \mathrm{H}$ NMR spectra of 2,3-diarylxanthones $7 \mathbf{b}-\mathbf{i}$ one can observe the singlets corresponding to the resonances of the methoxy protons $(\delta=3.52-3.90 \mathrm{ppm})$ whereas in the 2,3-diarylxanthones $\mathbf{9 b - i}$ these signals are absent and the singlets corresponding to the hydroxyl protons appear at higher frequency values $(\delta=8.94-9.67 \mathrm{ppm})$. HMBC and NOESY spectra were used for the structure assignment of 2,3-diaryl-3,4-dihydroxanthones $\mathbf{8 a - i}$, similarly to the procedure described in our previous work. ${ }^{13}$

In summary, a novel, efficient and general route for the synthesis of 2,3-diarylxanthones $7 \mathbf{a}-\mathbf{i}$ was developed. 3Bromo-2-styrylchromones $\mathbf{5 a}-\mathbf{c}$, the key intermediates in this synthetic process, were obtained by a novel one potreaction of 5-aryl-3-hydroxy-1-(2-hydroxyphenyl)-2,4pentadien-1-ones 4a-c with PTT. The Heck reaction of 3bromo-2-styrylchromones $\mathbf{5 a}-\mathbf{c}$ with styrenes $\mathbf{6 a}-\mathbf{c}$ led to the formation of methoxylated 2,3-diarylxanthones $7 \mathbf{a}-\mathbf{i}$ and 2,3-diaryl-3,4-dihydroxanthones $\mathbf{8 a - i}$ in a one-pot reaction. The final step consists of the cleavage of the methyl groups of $\mathbf{7 b}-\mathbf{i}$ to afford the desired hydroxylated and polyhydroxylated 2,3-diarylxanthones $\mathbf{9 b - i}$.

\section{Acknowledgment}

Thanks are due to the University of Aveiro, FCT and FEDER for funding the Organic Chemistry Research Unit and the project POCI/QUI/59284/2004. One of us (C.M.M. Santos) is also grateful to PRODEP 5.3 for financial support.

\section{References and Notes}

(1) (a) Hostettman, K.; Hostettman, M. In Methods in Plant Biochemistry, Plant Phenolics, Vol. 1; Dey, P. M.; Harbone, J. B., Eds.; Academic Press: London, 1989, 493.

(b) Bennett, G. J.; Lee, H.-H. Phytochemistry 1989, 28, 967. (c) Gales, L.; Damas, A. M. Curr. Med. Chem. 2005, 12, 2499.

(2) (a) Vieira, L. M. M.; Kijjoa, A. Curr. Med. Chem. 2005, 12, 2413. (b) Roberts, J. C. Chem. Rev. 1961, 591.

(3) Pinto, M. M. M.; Sousa, M. E.; Nascimento, M. S. J. Curr. Med. Chem. 2005, 12, 2517.

(4) (a) Dube, M.; Zunker, K.; Neidhart, S.; Carle, R.; Steinhart, H.; Paschke, A. J. Agric. Food Chem. 2004, 52, 3938. (b) Pfister, J. R.; Ferraresi, R. W.; Harrison, I. T.; Rooks, W. H.; Freid, J. H. J. Med. Chem. 1978, 21, 669.

(5) (a) Abdel-Lateff, A.; Klemke, C.; König, G. M.; Wright, A. D. J. Nat. Prod. 2003, 66, 706. (b) Fukai, T.; Yonekawa, M.; Hou, A.-J.; Nomura, T.; Sun, H.-D.; Uno, J. J. Nat. Prod. 2003, 66, 1118. (c) Mackeen, M. M.; Ali, A. M.; Lajis, N. H.; Kawazu, K.; Hassan, Z.; Amran, M.; Habsah, M.; Mooi, L. Y.; Mohamed, S. M. J. Ethanopharmacol. 2000, 72, 395.

(6) (a) Park, H. H.; Park, Y.-D.; Han, J.-M.; Im, K.-R.; Lee, B. W.; Jeong, I. Y.; Jeong, T.-S.; Lee, W. S. Bioorg. Med. Chem. Lett. 2006, 16, 5580. (b) Lin, C. N.; Chung, M. I.; Liou, S. J.; Lee, T. H.; Wang, J. P. J. Pharm. Pharmacol. 1996, 48, 532.

(7) (a) Riscoe, M.; Kelly, J. X.; Winter, R. Curr. Med. Chem. 2005, 12, 2539. (b) Portela, C.; Afonso, C. M. M.; Pinto, M.
M. M.; Ramos, M. J. Bioorg. Med. Chem. 2004, 12, 3313. (c) Dua, V. K.; Ojha, V. P.; Roy, R.; Joshi, B. C.; Valecha, N.; Devi, C. U.; Batnagar, M. C.; Sharma, V. P.; Subbarao, S. K. J. Ethanopharmacol. 2004, 95, 247.

(8) (a) Zhang, H.-Z.; Kasibhatla, S.; Wang, Y.; Herich, J.; Guastella, J.; Tseng, B.; Drewe, J.; Cai, S. X. Bioog. Med. Chem. 2004, 12, 309. (b) Rewcastle, G. W.; Atwell, G. J.; Zhang, L.; Baguley, B. C.; Denny, W. A. J. Med. Chem. 1991, 34, 217.

(9) (a) Merza, J.; Aumond, M.-C.; Rondeau, D.; Dumontet, V.; Le Ray, A.-M.; Séraphin, D.; Richomme, P. Phytochemistry 2004, 65, 2915. (b) Hay, A.-E.; Aumond, M.-C.; Mallet, S.; Dumontet, V.; Litaudon, M.; Rondeau, D.; Richomme, P. J. Nat. Prod. 2004, 67, 707. (c) Pauletti, P. M.; CastroGamboa, I.; Silva, D. H. S.; Young, M. C. M.; Tomazela, D. M.; Eberlin, M. N.; Bolzani, V. S. J. Nat. Prod. 2003, 66, 1384.

(10) (a) Park, K. H.; Park, Y.-D.; Han, J.-M.; Im, K.-R.; Lee, B. W.; Jeong, I. Y.; Jeong, T.-S.; Lee, W. S. Bioorg. Med. Chem. Lett. 2006, 16, 5580. (b) Lee, B. W.; Lee, J. H.; Lee, S.-T.; Lee, H. S.; Lee, W. S.; Jeong, T.-S.; Park, W. S. Bioorg. Med. Chem. Lett. 2005, 15, 5548.

(11) (a) Garrity, A. R.; Morton, G. A. R.; Morton, J. C. US Patent, 6730333, 2004. (b) Sellés, A. J. N.; Castro, H. T. V.; Agüero-Agüero, J.; González-González, J.; Naddeo, F.; De Simone, F.; Rastrelli, L. J. Agric. Food Chem. 2002, 50, 762.

(12) Sousa, M. E.; Pinto, M. M. M. Curr. Med. Chem. 2005, 12, 2447.

(13) Santos, C. M. M.; Silva, A. M. S.; Cavaleiro, J. A. S. Synlett 2005, 3095.

(14) (a) Mahal, H. S.; Venkataraman, K. J. Chem. Soc. 1934, 1767. (b) Baker, W. J. Chem. Soc. 1933, 1381.

(15) Typical Experimental Procedure: Phenyltrimethylammonium tribromide (PTT; $2.1 \mathrm{~g}, 5.5$ $\mathrm{mmol})$ was added to a THF $(60 \mathrm{~mL})$ solution of the appropriate 5-aryl-3-hydroxy-1-(2-hydroxyphenyl)-2,4pentadien-1-ones $4 \mathbf{a}-\mathbf{c}(5 \mathrm{mmol})$. The reaction mixture was stirred and allowed to stand at r.t. for $12 \mathrm{~h}$. After that period, the solution was poured into ice $(50 \mathrm{~g})$ and $\mathrm{H}_{2} \mathrm{O}(80 \mathrm{~mL})$, stirred for $20 \mathrm{~min}$ and the yellow solid was removed by filtration. The residue was taken in $\mathrm{CHCl}_{3}(50 \mathrm{~mL})$ and washed with $\mathrm{H}_{2} \mathrm{O}(3 \times 50 \mathrm{~mL})$. The organic layer was collected, the solvent was evaporated to dryness and the residue was purified by silica gel column chromatography using $\mathrm{CH}_{2} \mathrm{Cl}_{2}$ as eluent. The solvent was evaporated and the residue was recrystallized from $\mathrm{EtOH}$ to give the 3-bromo2 -styrylchromones $\mathbf{5 a}-\mathbf{c}$ in good yields $(\mathbf{5 a}$ : $67 \%$; 5 b: $53 \%$; 5c: $64 \%$ ).

(16) Physical Data of 3-Bromo-3', $\mathbf{4}^{\prime}$-dimethoxy-2-styrylchromone (5c): $\mathrm{mp} 187-189^{\circ} \mathrm{C} .{ }^{1} \mathrm{H}$ NMR $(300.13 \mathrm{MHz}$, $\mathrm{CDCl}_{3}$ ): $\delta=3.95$ (s, $\left.3 \mathrm{H}, 4^{\prime}-\mathrm{OMe}\right), 3.98$ (s, $3 \mathrm{H}, 3^{\prime}-\mathrm{OMe}$ ), $6.92\left(\mathrm{~d}, J=8.3 \mathrm{~Hz}, 1 \mathrm{H}, \mathrm{H}-5^{\prime}\right), 7.14$ (d, $J=2.0 \mathrm{~Hz}, 1 \mathrm{H}, \mathrm{H}-$ $\left.2^{\prime}\right), 7.24\left(\mathrm{dd}, J=2.0,8.3 \mathrm{~Hz}, 1 \mathrm{H}, \mathrm{H}-6^{\prime}\right), 7.33(\mathrm{~d}, J=15.8 \mathrm{~Hz}$, $1 \mathrm{H}, \mathrm{H}-\alpha$ ), 7.41 (ddd, $J=0.8,7.7,7.8 \mathrm{~Hz}, 1 \mathrm{H}, \mathrm{H}-6$ ), 7.53 (d, $J=7.9 \mathrm{~Hz}, 1 \mathrm{H}, \mathrm{H}-8), 7.66(\mathrm{~d}, J=15.8 \mathrm{~Hz}, 1 \mathrm{H}, \mathrm{H}-\beta), 7.70$ (ddd, $J=1.6,7.7,7.9 \mathrm{~Hz}, 1 \mathrm{H}, \mathrm{H}-7$ ), 8.23 (dd, $J=1.6,7.8$ $\mathrm{Hz}, 1 \mathrm{H}, \mathrm{H}-5) .{ }^{13} \mathrm{C}$ NMR $\left(75.47 \mathrm{MHz}, \mathrm{CDCl}_{3}\right): \delta=55.96$, 55.99 (3'-OMe, 4'-OMe), 109.0 (C-3), 109.6 (C-2'), 111.1 $\left(\mathrm{C}-5^{\prime}\right), 116.9(\mathrm{C}-\alpha), 117.4(\mathrm{C}-8), 122.1$ (C-10), 122.6 (C-6'), 125.3 (C-6), 126.4 (C-5), 127.9 (C-1'), 133.9 (C-7), 139.6 $(\mathrm{C}-\beta), 149.3\left(\mathrm{C}-3^{\prime}\right), 151.2\left(\mathrm{C}-4^{\prime}\right), 154.9(\mathrm{C}-9), 158.7(\mathrm{C}-2)$, $172.7(\mathrm{C}-4)$. MS $\left(\mathrm{ESI}^{+}\right): \mathrm{m} / z(\%)=387(19)\left([\mathrm{M}+\mathrm{H}]^{+},{ }^{79} \mathrm{Br}\right)$, $389(20)\left([\mathrm{M}+\mathrm{H}]^{+},{ }^{81} \mathrm{Br}\right), 409(9)\left([\mathrm{M}+\mathrm{Na}]^{+},{ }^{79} \mathrm{Br}\right), 411(9)$ $\left.\left([\mathrm{M}+\mathrm{Na}]^{+},{ }^{81} \mathrm{Br}\right), 425(4)([\mathrm{M}+\mathrm{K}]]^{+},{ }^{79} \mathrm{Br}\right), 427(4)([\mathrm{M}+$ $\left.\mathrm{K}]^{+},{ }^{81} \mathrm{Br}\right), 795(7)\left([2 \times \mathrm{M}+\mathrm{Na}]^{+},{ }^{79} \mathrm{Br}\right), 797(15)([2 \times \mathrm{M}+$ $\mathrm{Na}]^{+},{ }^{81} \mathrm{Br}$ ). Anal. Calcd for $\mathrm{C}_{19} \mathrm{H}_{15} \mathrm{BrO}_{4}: \mathrm{C}, 58.93 ; \mathrm{H}, 3.90$. Found: C, 58.53; H, 3.84 . 
(17) Fougerousse, A.; Gonzalez, E.; Brouillard, R. J. Org. Chem. $\mathbf{2 0 0 0}, 65,583$.

(18) (a) Trzeciak, A. M.; Ziółkoeski, J. J. Coord. Chem. Rev. 2007, 251, 1281. (b) Nicolaou, K. C.; Bulger, P. G.; Sarlah, D. Angew. Chem. Int. Ed. 2005, 44, 4442. (c) Farina, V. Adv. Synth. Catal. 2004, 346, 1553.

(19) Typical Experimental Procedure: To a mixture of the appropriate 3-bromo-2-styrylchromones $5 \mathbf{a}-\mathbf{c}(0.4 \mathrm{mmol})$, triphenylphosphine (10.5 mg, $0.04 \mathrm{mmol}$ ), tetrakis(triphenylphosphine)palladium(0) $(23.1 \mathrm{mg}, 0.02$ $\mathrm{mmol})$ and triethylamine $(55.8 \mu \mathrm{L}, 0.4 \mathrm{mmol})$ in $N$-methyl2-pyrrolidinone $(6 \mathrm{~mL})$ was added the appropriate styrene 6a-c $(2 \mathrm{mmol}$ for styrene $\mathbf{6 a}$ and $0.8 \mathrm{mmol}$ for styrenes $\mathbf{6 b}, \mathbf{c})$. The reaction mixture was stirred under different conditions of time and temperature according to the substituents in the compounds (Table 1). Then, the mixture was poured into $\mathrm{H}_{2} \mathrm{O}(20 \mathrm{~mL})$ and ice $(10 \mathrm{~g})$ and extracted with $\mathrm{Et}_{2} \mathrm{O}(4 \times 25 \mathrm{~mL})$ and dried over anhyd $\mathrm{Na}_{2} \mathrm{SO}_{4}$. The residue was evaporated, taken in $\mathrm{CH}_{2} \mathrm{Cl}_{2}(15 \mathrm{~mL})$ and purified by TLC (eluent: $\mathrm{CH}_{2} \mathrm{Cl}_{2}$-light petroleum, 7:3). Two spots were collected in each case: the major one, having higher $R_{f}$ value, consisted of 2,3-diarylxanthones $7 \mathbf{a}-\mathbf{i}$ and the minor one, with lower $R_{f}$ value, consisted of 2,3-diaryl3,4-dihydroxanthones 8a-i. The 2,3-diarylxanthones 7a-i were recrystallized from $\mathrm{EtOH}$ in yields presented in Table 1.

(20) Physical Data of 2-(4-Methoxyphenyl)-3-(3,4-dimethoxyphenyl)xanthone (7h): $\mathrm{mp} 148-150{ }^{\circ} \mathrm{C} .{ }^{1} \mathrm{H}$ NMR (300.13 MHz, $\mathrm{CDCl}_{3}$ ): $\delta=3.60$ (s, $\left.3 \mathrm{H}, 4^{\prime \prime}-\mathrm{OMe}\right), 3.80$ (s, 3 $\mathrm{H}, 4^{\prime}-\mathrm{OMe}$ ), 3.90 (s, $\left.3 \mathrm{H}, 3^{\prime \prime}-\mathrm{OMe}\right), 6.61$ (d, $J=2.0 \mathrm{~Hz}, 1 \mathrm{H}$, $\left.\mathrm{H}-2^{\prime \prime}\right), 6.81\left(\mathrm{~d}, J=8.8 \mathrm{~Hz}, 2 \mathrm{H}, \mathrm{H}-3^{\prime}, \mathrm{H}-5^{\prime}\right), 6.83(\mathrm{~d}, J=8.0$ $\left.\mathrm{Hz}, 1 \mathrm{H}, \mathrm{H}-5^{\prime \prime}\right), 6.90$ (dd, $\left.J=2.0,8.0 \mathrm{~Hz}, 1 \mathrm{H}, \mathrm{H}-6^{\prime \prime}\right), 7.11$ (d, $\left.J=8.8 \mathrm{~Hz}, 2 \mathrm{H}, \mathrm{H}-2^{\prime}, \mathrm{H}-6^{\prime}\right), 7.40$ (ddd, $J=0.9,7.7,7.8$ $\mathrm{Hz}, 1 \mathrm{H}, \mathrm{H}-7), 7.52$ (dd, $J=0.9,8.1 \mathrm{~Hz}, 1 \mathrm{H}, \mathrm{H}-5), 7.56$ (s, $1 \mathrm{H}, \mathrm{H}-4), 7.75$ (ddd, $J=1.7,7.7,8.1 \mathrm{~Hz}, 1 \mathrm{H}, \mathrm{H}-6), 8.33$ (s, $1 \mathrm{H}, \mathrm{H}-1), 8.37$ (dd, $J=1.7,7.8 \mathrm{~Hz}, 1 \mathrm{H}, \mathrm{H}-8) .{ }^{13} \mathrm{C}$ NMR $\left(75.47 \mathrm{MHz}, \mathrm{CDCl}_{3}\right): \delta=55.2\left(4^{\prime}-\mathrm{OMe}\right), 55.6$ (4"'-OMe), 55.8 (3"-OMe), 110.7 (C-5"), $113.2\left(\mathrm{C}-2^{\prime \prime}\right), 113.6$ (C-3', C5'), 118.0 (C-5), 119.0 (C-4), 120.4 (C-9a), 121.9 (C-8a, C$\left.6^{\prime}\right), 123.9(\mathrm{C}-7), 126.7$ (C-8), 128.1 (C-1), $130.9\left(\mathrm{C}-2^{\prime}, \mathrm{C}^{\prime} 6^{\prime}\right)$, 132.4, 132.5 (C-1', C-1"), 134.7 (C-6), 136.6 (C-2), 147.3 (C-3), 148.2, 148.5 (C-3", C-4"), 155.1 (C-4a), 156.3 (C4b), $158.6\left(\mathrm{C}-4^{\prime}\right), 177.0$ (C-9). MS (EI): $m / z(\%)=438(100)$ $\left[\mathrm{M}^{+} \cdot\right], 423(11), 407(14), 380(8), 363(8), 309(8), 308(31)$, 307 (25), 293 (14), 292 (12), 291 (12), 277 (10), 250 (7), 222 (6), 188 (24), 151 (8), 102 (9), 86 (8), 84 (11). Anal. Calcd for $\mathrm{C}_{28} \mathrm{H}_{22} \mathrm{O}_{5}: \mathrm{C}, 76.70, \mathrm{H}, 5.06$. Found: C, 76.41; H, 5.42.

(21) Physical Data of 2-(4-Methoxyphenyl)-3-(3,4-dimethoxyphenyl)-3,4-dihydroxanthone $(\mathbf{8 h})$ : yellow oil. ${ }^{1} \mathrm{H}$ $\operatorname{NMR}\left(300.13 \mathrm{MHz}, \mathrm{CDCl}_{3}\right): \delta=2.98$ (dd, $J=1.3,17.2 \mathrm{~Hz}$, $\left.1 \mathrm{H}, \mathrm{H}-4_{\text {trans }}\right), 3.62\left(\mathrm{dd}, J=8.8,17.2 \mathrm{~Hz}, 1 \mathrm{H}, \mathrm{H}-4_{\text {cis }}\right), 3.76(\mathrm{~s}$, $3 \mathrm{H}, 3^{\prime \prime}$-OMe), 3.79 (s, $\left.6 \mathrm{H}, 4^{\prime}-\mathrm{OMe}, 4^{\prime \prime}-\mathrm{OMe}\right), 4.22$ (dd, $J=$
$1.3,8.8 \mathrm{~Hz}, 1 \mathrm{H}, \mathrm{H}-3), 6.71\left(\mathrm{~d}, J=8.1 \mathrm{~Hz}, 1 \mathrm{H}, \mathrm{H}-5^{\prime \prime}\right), 6.81-$ 6.86 (m, 2 H, H-2", H-6"), 6.83 (d, J = 8.9 Hz, 2 H, H-3', H$\left.5^{\prime}\right), 7.36(\mathrm{~d}, J=8.0 \mathrm{~Hz}, 2 \mathrm{H}, \mathrm{H}-5), 7.38$ (ddd, $J=1.4,7.6,7.7$ $\mathrm{Hz}, 1 \mathrm{H}, \mathrm{H}-7), 7.44$ (s, $1 \mathrm{H}, \mathrm{H}-1), 7.44(\mathrm{~d}, J=8.9 \mathrm{~Hz}, 2 \mathrm{H}$, H-2', H-6'), 7.60 (ddd, $J=1.6,7.7,8.0 \mathrm{~Hz}, 1 \mathrm{H}, \mathrm{H}-6$ ), 8.28 $(\mathrm{dd}, J=1.6,7.6 \mathrm{~Hz}, 1 \mathrm{H}, \mathrm{H}-8) .{ }^{13} \mathrm{C}$ NMR $(75.47 \mathrm{MHz}$, $\left.\mathrm{CDCl}_{3}\right): \delta=36.8(\mathrm{C}-4), 41.4(\mathrm{C}-3), 55.3,55.75,55.80$ (4'$\left.\mathrm{OMe}, 3^{\prime \prime}-\mathrm{OMe}, 4^{\prime \prime}-\mathrm{OMe}\right), 110.4\left(\mathrm{C}-2^{\prime \prime}\right), 111.4\left(\mathrm{C}-5^{\prime \prime}\right), 113.9$ (C-3', C-5'), 114.8 (C-1), 116.9 (C-9a), 118.0 (C-5), 119.2 (C-6"), 123.8 (C-8a), 125.0 (C-7), 126.2 (C-8), 126.9 (C-2', C-6'), 131.7 (C-1'), 132.9 (C-6), 133.1 (C-1"), 135.3 (C-2), 148.0 (C-4"), 149.1 (C-3"), 155.9 (C-4b), $159.2\left(\mathrm{C}-4^{\prime}\right)$, 162.2 (C-4a), 174.2 (C-9). MS (EI): $m / z(\%)=440$ (13) [M+.], 439 (26), 438 (100), 423 (13), 497 (14), 391 (7), 380 (7), 363 (7). HRMS (EI): $\mathrm{m} / z$ calcd for $\mathrm{C}_{28} \mathrm{H}_{24} \mathrm{O}_{5}$ : 440.1624 ; found: 440.1624 .

(22) (a) Punna, S.; Meunier, U. H.; Finn, M. G. Org. Lett. 2004, 6, 2777. (b) Nordvik, T.; Brinker, U. H. J. Org. Chem. 2003, 68, 9394.

(23) Typical Experimental Procedure: A solution of the appropriate 2,3-diarylxanthones $\mathbf{7 b}-\mathbf{i}$ in freshly distilled $\mathrm{CH}_{2} \mathrm{Cl}_{2}(3 \mathrm{~mL})$ was cooled to $-78^{\circ} \mathrm{C}$ under nitrogen. A solution of $\mathrm{BBr}_{3}$ in $0.1 \mathrm{M} \mathrm{CH}_{2} \mathrm{Cl}_{2}$ (2.5 equiv for each methyl group to be cleaved) was gradually added. The reaction mixture was stirred at r.t. for a period of time according to the substituents in the compounds ( $1 \mathrm{~h}$ for each group to be cleaved). After that period, the solution was poured into $\mathrm{H}_{2} \mathrm{O}$ $(20 \mathrm{~mL})$ and vigorously stirred until the formation of a yellow precipitate. The solid was washed abundantly with $\mathrm{H}_{2} \mathrm{O}(4 \times 50 \mathrm{~mL})$ and then with light petroleum $(4 \times 20 \mathrm{~mL})$ to afford the hydroxylated 2,3-diarylxanthones $9 \mathbf{b}-\mathbf{i}$ in good yields (9b: 72\%; 9c: 80\%; 9d: 82\%; 9e: 94\%; 9f: 80\%; 9g: 80\%; 9h: 94\%; 9i: $70 \%)$.

(24) Physical Data of 2-(4-Hydroxyphenyl)-3-(3,4-dihydroxyphenyl)xanthone (9h): $\mathrm{mp} 277-279{ }^{\circ} \mathrm{C} .{ }^{1} \mathrm{H}$ NMR $\left(300.13 \mathrm{MHz}\right.$, DMSO- $\left.d_{6}\right): \delta=6.50(\mathrm{dd}, J=2.0,8.1 \mathrm{~Hz}, 1 \mathrm{H}$, H-6"), 6.62 (d, $\left.J=2.0 \mathrm{~Hz}, 1 \mathrm{H}, \mathrm{H}-2^{\prime \prime}\right), 6.67$ (d, $J=8.1 \mathrm{~Hz}, 1$ $\left.\mathrm{H}, \mathrm{H}-5^{\prime \prime}\right), 6.70$ (d, J= 8.4 Hz, $\left.2 \mathrm{H}, \mathrm{H}-3^{\prime}, \mathrm{H}-5^{\prime}\right), 6.99$ (d, $J=$ $\left.8.4 \mathrm{~Hz}, 2 \mathrm{H}, \mathrm{H}-2^{\prime}, \mathrm{H}^{\prime} 6^{\prime}\right), 7.50$ (dd, $J=7.6,7.7 \mathrm{~Hz}, 1 \mathrm{H}, \mathrm{H}-7$ ), 7.52 (s, $1 \mathrm{H}, \mathrm{H}-4), 7.68$ (d, $J=8.1 \mathrm{~Hz}, 1 \mathrm{H}, \mathrm{H}-5), 7.89$ (ddd, $J=1.5,7.6,8.1 \mathrm{~Hz}, 1 \mathrm{H}, \mathrm{H}-6), 8.01(\mathrm{~s}, 1 \mathrm{H}, \mathrm{H}-1), 8.22$ (dd, $J=1.5,7.7 \mathrm{~Hz}, 1 \mathrm{H}, \mathrm{H}-8), 8.97$ (s, $\left.1 \mathrm{H}, 4^{\prime \prime}-\mathrm{OH}\right), 9.15$ (s, $1 \mathrm{H}$, $\left.3^{\prime \prime}-\mathrm{OH}\right), 9.51$ (s, $\left.1 \mathrm{H}, 4^{\prime}-\mathrm{OH}\right) .{ }^{13} \mathrm{C} \mathrm{NMR}(75.47 \mathrm{MHz}$, DMSO- $\left.d_{6}\right): \delta=115.1\left(\mathrm{C}-3^{\prime}, \mathrm{C}-5^{\prime}\right), 115.5\left(\mathrm{C}-5^{\prime \prime}\right), 116.9(\mathrm{C}-$ 2"), 118.3 (C-5), 118.9 (C-4), 119.6 (C-9a), 120.8 (C-6"), 121.3 (C-8a), 124.4 (C-7), 126.1 (C-8), 127.0 (C-1), 130.5 $\left(\mathrm{C}-1^{\prime}, \mathrm{C}-2^{\prime}, \mathrm{C}-6^{\prime}\right), 130.7$ (C-1"'), 135.5 (C-6), 136.6 (C-2), 145.0 (C-3"), 145.3 (C-4"), 147.7 (C-3), 154.4 (C-4a), 155.8 (C-4b), $156.4\left(\mathrm{C}-4^{\prime}\right), 175.7$ (C-9). MS (EI): $\mathrm{m} / \mathrm{z}(\%)=396$ (100) $\left[\mathrm{M}^{+} \cdot\right], 395$ (6), 380 (7), 379 (11), 349 (8), 98 (10), 97 (10), 83 (10). HRMS (EI): $\mathrm{m} / z$ calcd for $\mathrm{C}_{25} \mathrm{H}_{16} \mathrm{O}_{5}$ : 396.0998; found: 396.0996 . 